\title{
Vacant mitochondria in the myocardium of a patient with mitochondrial cardiomyopathy and diabetes mellitus
}

\author{
Takao Kato, Sayako Hirose, Ryuji Nohara \\ Department of Cardiovascular Medicine, The Tazuke Kofukai Medical Research Institute, Kitano Hospital, Osaka, Japan
}

Correspondence to Dr Takao Kato, takao-kato@kitano-hp.or.jp

\section{DESCRIPTION}

A 67-year-old woman was referred for heart failure, New York Heart Association class 2. Her medical history included: 25 years of diabetes, 7 years of hearing disorder and 3 years of mild cognitive dysfunction, with a family history of diabetes of her mother. She had been diagnosed with a point mutation of mitochondrial DNA 3243 (A-G) 3 years ago. Echocardiography revealed systolic and diastolic dysfunction with concentric left ventricular hypertrophy (figure 1A). Endomyocardial biopsy was performed, and light microscopy showed disarranged myocardial fibres with vacuolation (figure $1 \mathrm{~B}$ ). Electron microscopy revealed a marked increase of mitochondria that were vacant inside without a cristae structure, disarranged along with the myocardial fibres, and deformed into various sizes (figure $2 \mathrm{~A}, \mathrm{~B}$ ). The final diagnosis was mitochondrial cardiomyopathy along with maternally inherited diabetes and deafness. The identification of vacant mitochondria in this patient made us choose the energy-sparing therapy using a $\beta$-blocker with $5 \mathrm{mg}$ a day of carvedilol and an ACE inhibitor with $5 \mathrm{mg}$ a day of enarapril for the treatment of heart failure at first.
Considering the increasing number of patients with diabetes mellitus and about $1 \%$ of the diabetic population being thought to have point mutation of a mitochondrial gene in different races, ${ }^{1}$ the importance in mitochondrial cardiomyopathy due to mitochondrial gene mutation has been more strongly recognised. This type of mitochondrial diabetes, which is called maternally inherited diabetes and deafness, is characterised by deafness in more than $60 \%$, ${ }^{2}$ cognitive impairment, and heart failure, though generally long after the onset of diabetes.

\section{Learning points}

- About $1 \%$ of the diabetic populations have point mutation of mitochondrial gene.

- Mitochondrial cardiomyopathy is one of differential diagnoses if patients had deafness, cognitive impairment and diabetes.

- Vacant mitochondria and other structural abnormalities were observed in mitochondrial cardiomyopathy.

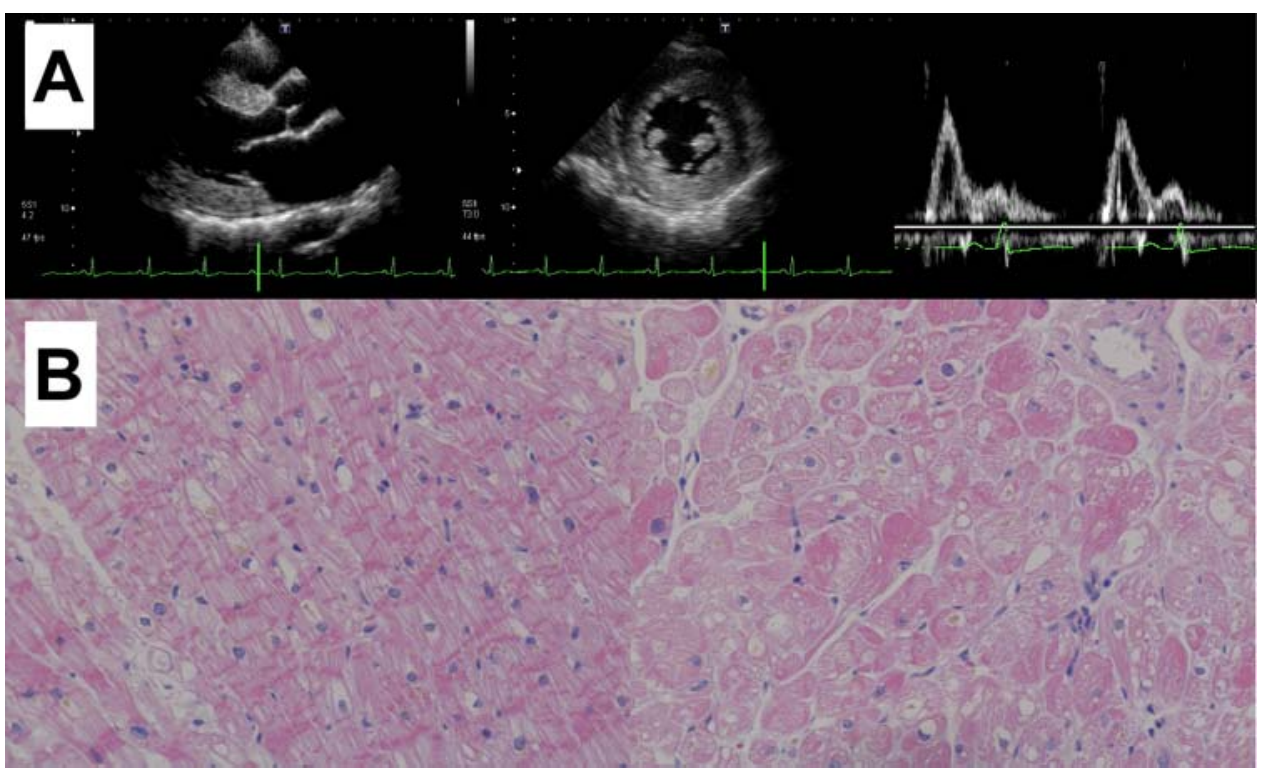

Figure 1 (A) Representative images of echocardiography. Systolic dysfunction with $42 \%$ ejection fraction, hypertrophy of a 12-mm wall thickness, and a restrictive filling pattern of transmitral flow with an E/A of 2.54 and 142-ms deceleration time was observed. (B) H\&E staining. 


\section{BMJ Case Reports}

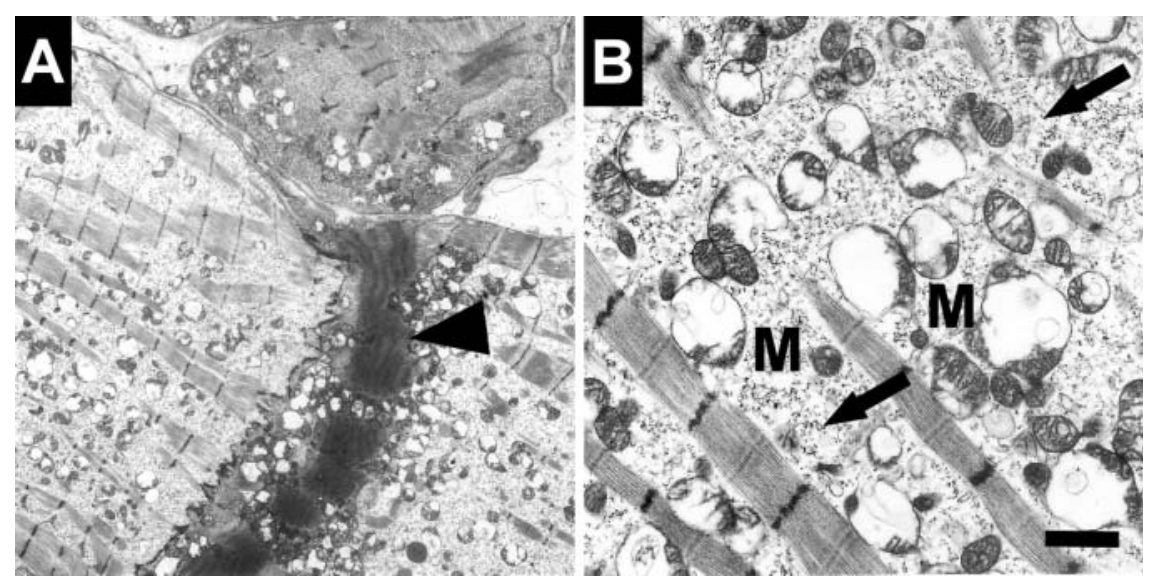

Figure 2 Vacant mitochondria observed by electron microscopy. $M$, mitochondria; arrowhead, a condensed $Z$ band with the concentration of abnormal mitochondria; black arrow, the area replaced by glycogen. Magnification, (A) $3000 \times$ and (B) $12000 \times$.

\section{Competing interests None.}

Patient consent Obtained.

\section{REFERENCES}

1. Murphy R, Turnbull DM, Walker $M$, et al. Clinical features, diagnosis and management of maternally inherited diabetes and deafness (MIDD) associated with the $3243 \mathrm{~A}>\mathrm{G}$ mitochondrial point mutation. Diabet Med. 2008;25:383-99.

2. Gerbitz KD, van den Ouweland JM, Maassen JA, et al. Mitochondrial diabetes mellitus: a review. Biochim Biophys Acta 1995;1271:253-60.

This pdf has been created automatically from the final edited text and images.

Copyright 2012 BMJ Publishing Group. All rights reserved. For permission to reuse any of this content visit http://group.bmj.com/group/rights-licensing/permissions.

BMJ Case Report Fellows may re-use this article for personal use and teaching without any further permission.

Please cite this article as follows (you will need to access the article online to obtain the date of publication).

Kato T, Hirose S, Nohara R. Vacant mitochondria in the myocardium of a patient with mitochondrial cardiomyopathy and diabetes mellitus. BMJ Case Reports 2012;10.1136/bcr-2012-006645, Published XXX

Become a Fellow of BMJ Case Reports today and you can:

- Submit as many cases as you like

- Enjoy fast sympathetic peer review and rapid publication of accepted articles

- Access all the published articles

- Re-use any of the published material for personal use and teaching without further permission

For information on Institutional Fellowships contact consortiasales@bmjgroup.com

Visit casereports.bmj.com for more articles like this and to become a Fellow 